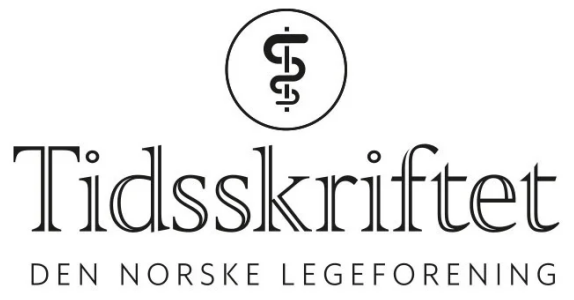

\title{
Rettelse: Sykehusinnleggelser med covid-19 - en sammenligning av ulike datakilder
}

RETTELSE

ROBERT WHITTAKER

MARI GRØSLAND

EIRIK ALNES BUANES

SIGRID BEITLAND

BENTE BRYHN

JON HELGELAND

OLAV ISAK SJØFLOT

JACOB DAG BERILD

ELINA SEPPÄLÄ

RAGNHILD TØNNESSEN

KJETIL TELLE

Tidsskr Nor Legeforen 2020; 140: 1891-6. 
I Tidsskriftet nr. 18/2020, s. 1892 skal det i Tabell 1 stå: Pasienter med laboratoriebekreftet covid-19 som var inneliggende på sykehus i perioden to dager før til 14 dager etter prøvedato og/eller pasienter diagnostisert med Uo7.1 under innleggelsen.

Vi beklager feilen, den er rettet på nett.

Publisert: 17. november 2021. Tidsskr Nor Legeforen. DOI: 10.4045/tidsskr.21.0785

(C) Tidsskrift for Den norske legeforening 2023. Lastet ned fra tidsskriftet.no 26. april 2023. 